\title{
IAMJ
}

INTERNATIONAL

AYURVEDIC

MEDICAL JOURNAL

ISSN: 2320-5091

Impact Factor: 6.719

\section{HITKAR AAHARA PROMOTES HEALTHY LIFESTYLE - A REVIEW STUDY}

\section{$\underline{\text { Sonali Sanjay Vathare }}{ }^{1}$, Varsharani Santosh Niphade $^{2}$, Ankush Haushiram Gunjal $^{3}$, Satish Digambar Urhe $^{4}$}

${ }^{1}$ PG Scholar Department of Kaychikitsa

${ }^{2} \mathrm{HOD} \&$ Associate Prof. Department of Kaychikitsa

${ }^{3}$ Associate Professor Department of Kaychikitsa

${ }^{4}$ Assist. Professor Department of Panchakarma

SMBT Ayurved College \& Hospital, Nandi Hills, Dhamangaon, Nashik, Maharashtra, India

Corresponding Author:indrayani.vathare10@gmail.com

https://doi.org/10.46607/iamj08p5032021

(Published online: March 2021)

Open Access

(C) International Ayurvedic Medical Journal, India 2021

Article Received:04/03/2021 - Peer Reviewed:09/03/2021 - Accepted for Publication:10/03/2021

Check for updates

\section{ABSTRACT}

Hita Aahara is responsible for the happiness and formation of the healthy body. Food affect mind also it increases or decreases the qualities of mind i.e. Satvaguna, Rajoguna, Tamoguna. In classical textbook distributed age groups according to nutrition requirement as Infants (Ksheerada), Children's (Ksheera Annada), Teenagers (Annada). In classical textbook Shadras Aahar helps to taste for tongue and Truptikar for mind and helps to growth and development of healthy body. So, that it is said in ancient Indian literature that if dietetics is followed, medicine is not needed and if dietetics is not observed even medicine are not useful. Specially it divides Hitkar Aahara, Ahitkar Aahara according to age distribution explain in classical text.

Keywords: Aahara, Hitkar, Ahitkar, Shadras

\section{INTRODUCTION}

In Ayurveda where advantageous and disadvantageous as well as happy and unhappy (state of) life along with what is good or bad for life its measurement and life itself are described. ${ }^{(1)}$ Good health stands 
at the very root of virtuous acts acquirement of wealth, gratification of desire and final emancipation. ${ }^{(2)}$ Generic concomitance is always the cause of the augmentation of all the beings whereas the variant factor of their diminution provided both are applied. ${ }^{(3)}$ Lord Atreya said - wholesome food is one of the causes for the growth of living beings and unwholesome food for the growth of disease. ${ }^{(4)}$ Food is article which maintain the equilibrium of bodily Dhatus and help in eliminating the disturbance of their equilibrium are to be regard as wholesome, otherwise they are unwholesome. There are the most accurate definition of wholesome and unwholesome food articles. ${ }^{(5)}$ The body as well as diseases are caused by food, wholesome and unwholesome food are responsible for happiness and misery respectively individuals who have immunity from and susceptibility to the various psychosomatic disease various diseases specific to each of the Dhatus ( tissue element) ${ }^{(6)}$.

\section{Literature Review -}

A) Previous work done -

1) Concept of Aahara in Ayurveda, IAMJ Volume 6 Issues 5 May 2018

2) Critical review of dietetics in Ayurved, Research gate Oct 2016

3) Viruddhahara an Ayurvedic approach to dietary incompatibilities - A review, WJP vol 4, Issue 3, Page no 66 to 69,2018

B) Ayurvedic literature review -

a) Samhita -

1. Charaka Samhita Sutrasthana - Yajjapurishaya Aadhyaya - Hit Ahit Aahara Lakshana

2. Kashyap Samhita Uttarsthana Balamayapratishedham Aadhyaya - Age distribution

3. Sushruta Samhita Sutrasthana - Annapanvidhi Aadhyaya - Aahara Prashasti.

\section{Materials and Methods}

Critical Analysis of classical textbooks and relevant research material like Charak Samhita, Sushruta Samhita, Ashtag Hruday. Journals, Research Article, Textbooks was carried out studied and reviewed. Result of these data mining has been presented in the research article.
OBSERVATION: Ancient treatise describes Trayopsthambha which includes Aahar, Nidra, and Bramhacharya. Aahara is having prime importance as it maintains the equilibrium of bodily Dhatus and help in eliminating the disturbance of their equilibrium are to be regard as wholesome, otherwise they are unwholesome. It can be the most accurate definition of wholesome and unwholesome food articles. ${ }^{(5)}$

Ahstang Hruday and Kashyap Samhita describes Hitkar and Ahitkar Aahara. According to age groups as Infants, Children's, Teenagers, And Elders explained in table no 1.ShadrasAahara can develop Saptadhatu Poshan, good health, digest the food and good salivation.${ }^{(9)}$ Food accrue, growth, strength, health, colour of the body and keenness of the sense organs, and that improper use of food leads to ill health. ${ }^{(10)}$ Hitkar Aahara and Ahitkar Aahara divides on Prakruti it is mentioned in Ayurvedic classical text. In Charak Agryaganya Hitkar Aahara like Ksheeram Jeevniyanam, Mansa Bruhaniyanam, Kukuto Balyanam, Annam Vruttikaranam to promote for healthy lifestyle. And Ahitkar Aahara Jambavm Vatajanananam, Shashkulya, Masha Shleshmapittajanananam, Kultha Amlapittajanananam it produces the various types of diseases like obesity, Skin infection, Diabetes. ${ }^{(11)}$ In AshtangSangraha Hitkar Aahara Ksheer GrutaabhyasoRasayananam, Madhukam Chakshushya Vrushya Keshya Kanthya Varnya and Ahitkar Aahara Vrudhaveeryashanm Ninditvayadhikaranam, Gurubhojanm Durvipakanam, Atimatrashanmamdosh Hetunam. ${ }^{(12)}$

\section{DISCUSSION}

The food is said to be cause of stability for all living beings. There is nothing else except diet for sustaining the life of living being. Benefits of Hitkar AaahraImproved memory and brain health, Better mood and energy level, Strong bones, Maintain Heart health, Improved gut health. Healthy food basically unprocessed, Low calories, increases immunity, Improve sleep quality. Mind, Soul and Body these are three like a 'Tripod' the world is sustained by their combination, they constitute the substratum for everything. ${ }^{(13)}$ In India national health programs, National Maternal and Child health programs, Nutrition Pro- 
gram like Mid-day meal program Rashtriya Bal Swasthya Karyakram (RBSK) is stared for Malnutrition of children's, Women and child development program. To avoid the Malnourishment of child in urban areas. Ayurvedic concept of Hitkar And Ahitkar Aahara can be adopted in above mentioned national health programmes.

Table 1: Hitkar and Ahitkar Aahara according to age groups

\begin{tabular}{|c|c|c|}
\hline $\operatorname{Age~Groups}^{(7 / 8)}$ & Hitkar Aahara & Ahitkar Aahara \\
\hline $\begin{array}{l}\text { Infants }(\text { ssheerad }) \\
(0 \text { to } 1 \text { yrs })\end{array}$ & Stanya, Goksheer, Goghruta, Aja ksheer & Ushtra Ksheer, Aviksheer \\
\hline $\begin{array}{l}\text { Children's (ksheeran- } \\
\text { nad) (1 to 2yrs) }\end{array}$ & Goksheer, Goghruta, Madhu, Mansras, Manda, Peya, Vilepi & $\begin{array}{l}\text { Milk with Biscuits, Milk Shakes, flavored } \\
\text { milk, packed food like Maggi, Soups }\end{array}$ \\
\hline $\begin{array}{l}\text { Adults (Annad) } \\
\text { ( } 2 \text { to } 70 \mathrm{yrs})\end{array}$ & $\begin{array}{l}\text { Lohitshali, Godhoom, Patala, Mudga, Kulatha, Rajmasha, } \\
\text { Chana, Aantariksha Jal, Sandhav, Jeevanti, Aineyamansa, } \\
\text { Lava Pakshi, Godha, Rohit Matsya, Goghrut, Godugdha, } \\
\text { Tiltaila, Erandataila, Sarshaptaila, Atasitaila, Varah Vasa, } \\
\text { Chuluki Vasa, Pak Hans Vasa, Kukut Vasa, Aja Meda, } \\
\text { Aadrak, Mrudvika, Kharjura, Falgu, Aamratak, Aamalak, } \\
\text { Dadim, Sharkara }\end{array}$ & $\begin{array}{l}\text { Yava,Masha, Varsha rutunadi ka Jal, } \\
\text { Aoushar, Sarshap, Gomans, Kankapot, Man- } \\
\text { duk, Chilchim, Meshighruta, Meshidugdha, } \\
\text { KusumbhaTaila, Mahisha vasa, Kumbhir } \\
\text { vasa, Kakmudga vasa, Chatak vasa, Has- } \\
\text { timedas, Aaluk, Lakuch, Fanit }\end{array}$ \\
\hline $\begin{array}{l}\text { Elders (Jara/ Vrudha- } \\
\text { vashta) (more than } 70 \text { ) }\end{array}$ & Manda,Peya, Vilepi, Goksheer, Goghruta & \\
\hline
\end{tabular}

\section{CONCLUSION}

All living beings in the universe require food as it sustains the life of living beings. A self-disciplined man lives for hundred years free from disease by the intake of wholesome food. We should adopt healthy and Hitkar Aahara mentioned in classical as Complexion, Clarity, Good voice, Longevity, Geniuses, Happiness, Satisfaction, Nourishment, Strength and Intellect are all conditioned by food. Ahitkar Ahaara results in long term damages, going for unhealthy food stuffed like French fries, pizza can increase your risk of developing depression, obesity, heart disease, cancer. Hence, Ayurvedic concept of Hitkar And Ahitkar Aahara can be adopted for longevity and healthy wellbeing of an individual.

\section{REFERENCES}

1. Aacharya Vidhyadhar Shukla, Ravidatta Tripathi, Charaksamhita, choukhamba Prakashan, Reprint 2013, Sutrasthan 1/41 page No 11 .

2. Aacharya Vidhyadhar Shukla, Ravidatta Tripathi, Charak Samhita, choukhamba Prakashan, Reprint 2013, Sutrasthan 1/15 page No 4.

3. Aacharya Vidhyadhar Shukla, Ravidatta Tripathi, Charak Samhita, Choukhamba Prakashan, Reprint 2013, Sutrasthan 1/44 page No 13.

4. Aacharya Vidhyadhar Shukla, Ravidatta Tripathi, Charak Samhita, Choukhamba Prakashan, Reprint 2013, Sutrasthan 25/31 page No 333
5. Aacharya Vidhyadhar Shukla, Ravidatta Tripathi, Charak Samhita, Choukhamba Prakashan, Reprint 2013, Sutrasthan 25/33 page No 334.

6. Aacharya Vidhyadhar Shukla, Ravidatta Tripathi, Charak Samhita, Choukhamba Prakashan, Reprint 2013, Sutrasthan 28/45 page No 433.

7. Aacharya Kaviraj Atridev Gupta, Ashtag Sangrah, Chowkhamba Academy Varanasi, Reprint 2005, Uttartantra $3 / 2$ page no, 185 .

8. Dr Ashok more, Koumarbhrutya, Advyat Prakashn, Reprint Nov 2010, Adhyay 2, page no 18.

9. Dr Ganesh Garde, Sarth Vagbhat, Chokhamba Prakashan, Reprint 2012, Sutrasthan 3/57, page no 15

10. Dr Ambikadatta Shastri, Sushrut Samhita, Choukhaba Prakashan, Reprint 2014, Sutra Sthan 46/3, page no 241,242

11. Aacharya Vidhyadhar Shukla, Ravidatta Tripathi, Charak Samhita, Choukhamba Prakashan, Reprint 2013, Sutrasthan 25/40 page No 33

12. Kaviraj Atridev Gupta, Ashtang Sangrah, Choukhaba Prakashan, Reprint 2005, Sutrasthan 13/3, Page No 128

13. Aacharya Vidhyadhar Shukla, Ravidatta Tripathi, Charak Samhita, Choukhamba Prakashan, Reprint 2013, Sutrasthan 1/46 page No 17

\section{Source of Support: Nil \\ Conflict of Interest: None Declared}

How to cite this URL: Sonali Sanjay Vathare et al: Hitkar Aahara Promotes Healthy Lifestyle - A Review Study. International Ayurvedic Medical Journal \{online\} 2021 \{cited March, 2021\} Available from: http://www.iamj.in/posts/images/upload/2817_2819.pdf 